\title{
Numerical analysis of spark plugs number influence on selected parameters of combustion in piston engine
}

\begin{abstract}
The results of numerical analysis of combustion in multi-spark plug SI engine are presented in the paper. The outcome of computational analysis of lean mixtures combustion in engine with one and two spark plugs are compared. The output data was presented in graphical form as screenshots (temperature distribution) and as pressure and temperature courses in function of crank angle. 3D numerical modelling of combustion in multi-spark plug engine proved that improvement in lean mixture combustion process can be obtained by increasing the number of active ignition points. As conclusion it can be stated that numerical modelling results confirmed the favourable influence of applying two active spark plugs in lean mixtures combustion.
\end{abstract}

Key words: multi-spark plug engine, air excess number, lean mixture, mass fraction burnt ratio

\author{
Analiza numeryczna wpływu liczby świec zapłonowych \\ na wybrane parametry procesu spalania w silniku tłokowym
}

$W$ artykule przedstawiono analize numeryczna procesu spalania $w$ wieloświecowym silniku ZI. Porównano wyniki modelowania procesu spalania mieszanek zubożonych w silniku z jedna oraz dwoma świecami zapłonowymi. Dane wyjściowe zaprezentowano $w$ postaci graficznej, jako slajdy (rozkład temperatury) oraz jako przebiegi ciśnienia w funkcji kąta obrotu watu korbowego. Modelowanie trójwymiarowe procesu spalania w silniku wieloświecowym pokazało, że zwiększenie liczby czynnych świec zapłonowych znaczaco poprawia proces spalania mieszanek zubożonych. Główna wada tych mieszanek, jaka jest powolne, a wręcz przewlekte spalanie została $w$ dużym stopniu zniwelowana.

Słowa kluczowe: silnik wielowiecowy, współczynnik nadmiaru powietrza, mieszanka uboga, współczynnik wypalenia paliwa

\section{Introduction}

Since many years in the Institute of Internal Combustion Engines and Control Engineering at the Czestochowa University of Technology one of the direction of research has been 3D modelling of thermal and flow processes occurring in combustion chamber of piston engine with the use of KIVA-3V software [1]. Flow processes in the engine cylinder including liquid fuel injection [8], influence of flow parameters and pressure of gaseous medium on spark ignition process and the development of flame in the cylinder [3], and two-stage combustion process in the engine with pre-chamber fuelled by lean mixtures of air excess number $\lambda \leq 2.0[5]$ have been numerically analyzed.

The paper presents numerical analysis of combustion process in the engine with two spark plugs, fuelled by lean mixtures of air excess number $\lambda \leq 2.0$.

Introducing of the severe regulations concerning toxic components emitted by piston engines forces the development of engine design. Effective reduction of toxic components emission as well as the increase of SI engines efficiency can be obtained by lean mixtures combustion. However, it is connected with certain difficulties, such as: decrease in flame propagation velocity and high unrepeatability of engine work. These inconveniences can be partly leveled down for example by introducing of multipoint ignition $[6,9]$.

\section{Numerical analysis of combustion process}

Numerical modelling was performed in KIVA-3V code [1]. The software enabled 3D modelling of flows in piston

\section{Wstęp}

W Instytucie Maszyn Tłokowych i Techniki Sterowania Politechniki Częstochowskiej od wielu lat jednym z kierunków badań jest modelowanie 3D procesów cieplnych i przepływowych, zachodzących w komorze spalania silnika tłokowego, przy wykorzystaniu programu KIVA-3V [1]. Analizie numerycznej poddaje się m.in. procesy przepływowe w cylindrze silnika $\mathrm{z}$ uwzględnieniem procesu wtrysku paliwa ciekłego [8], wpływ parametrów przepływowych oraz ciśnienia medium gazowego na przebieg procesu zapłonu i rozwoju płomienia w cylindrze [3] oraz proces dwustopniowego spalania $\mathrm{w}$ silniku z komorą wstępną, zasilanym mieszankami ubogimi o współczynniku nadmiaru powietrza $\lambda \leq 2,0[5]$.

$\mathrm{W}$ niniejszym artykule przedstawiono natomiast analizę numeryczną procesu spalania w silniku z zapłonem dwuświecowym, zasilanym mieszankami ubogimi o współczynniku nadmiaru powietrza $\lambda \leq 2,0$.

Wprowadzanie coraz to ostrzejszych norm dotyczących składników toksycznych emitowanych przez silniki tłokowe wymusza zmiany w konstrukcji tych silników. Skuteczne obniżenie emisji składników toksycznych oraz zwiększenie sprawności silników ZI można uzyskać dzięki spalaniu mieszanek zubożonych. Wiąże się to jednak z pewnymi problemami, takimi jak np. spadek szybkości rozprzestrzeniania się płomienia, czy też duża niepowtarzalność pracy silnika. Niedogodności te można częściowo zniwelować m.in. przez wprowadzenie właśnie zapłonu wielopunktowego $[6,9]$. 
engine combustion chambers of various geometry with taking turbulence and heat exchange into consideration. The geometric mesh (Fig. 1) of modelled combustion chamber was designed on the basis of S320 ER spark ignited test engine geometry [2]. The simulation of combustion process was performed for liquid fuel (gasoline) at three air excess number values ( $\lambda=1.2,1.6$ and 2.0) and for two active spark plugs configurations as follows: 1 and 1-2. Location of spark plugs in combustion chamber is depicted in Fig. 2.

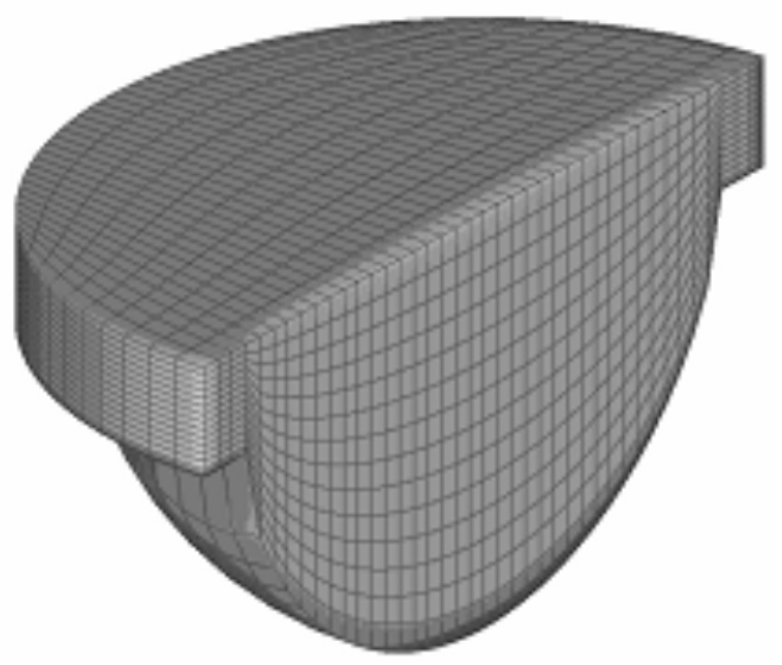

Fig. 1. Geometric mesh in Cartesian coordinate system

Rys. 1. Siatka geometryczna w prostokątnym uktadzie wspótrzędnych

3D modelling of combustion process started at $220 \mathrm{CA}$ (crank angle) and finished $494 \mathrm{CA}$, which corresponds to experimental engine camshaft phases, which are inlet valves closure and beginning of outlet valves opening. The program input data was derived from experiment [2], e.g. the ignition advance angle was set at $354 \mathrm{CA}$ for $\lambda=1.2,350 \mathrm{CA}$ for $\lambda=1.6$ and 344 CA for $\lambda=2.0$.

The output data was presented in graphical form as screenshots generated by GMV [1] postprocessor and as pressure courses (mean values for cylinder volume) in function of crank angle.

Following figures present temperature distribution in combustion chamber of modelled engine for specific values of air excess number and chosen active spark plugs configuration as well as pressure courses in function of crank angle. The spatial temperature distribution is depicted at piston location at Top Dead Centre.

Temperature distribution as well as pressure courses in function of crank angle at air excess number equal 1.2 are shown in Figs 3 to 5.

Figures 3 and 4 reveals that application of two spark plugs made the combustion process faster as greater fuel fraction was burnt and high temperature of $2000 \mathrm{~K}$ is obtained. The maximal temperature in cylinder has also been increased and at TDC it gained the value of approximately $2700 \mathrm{~K}$ in case of two active spark plugs and approximately $2500 \mathrm{~K}$ in case of one active spark plug.

\section{Analiza numeryczna procesu spalania}

Modelowanie numeryczne przeprowadzono za pomocą programu KIVA-3V [1], który pozwala na obliczanie przepływów trójwymiarowych w komorach silników spalinowych o dowolnej geometrii, z uwzględnieniem turbulencji oraz wymiany ciepła ze ściankami. Siatkę geometryczną (rys. 1) opisującą kształt komory spalania wykonano na podstawie danych rzeczywistego silnika badawczego ZI typu S320 ER [2].

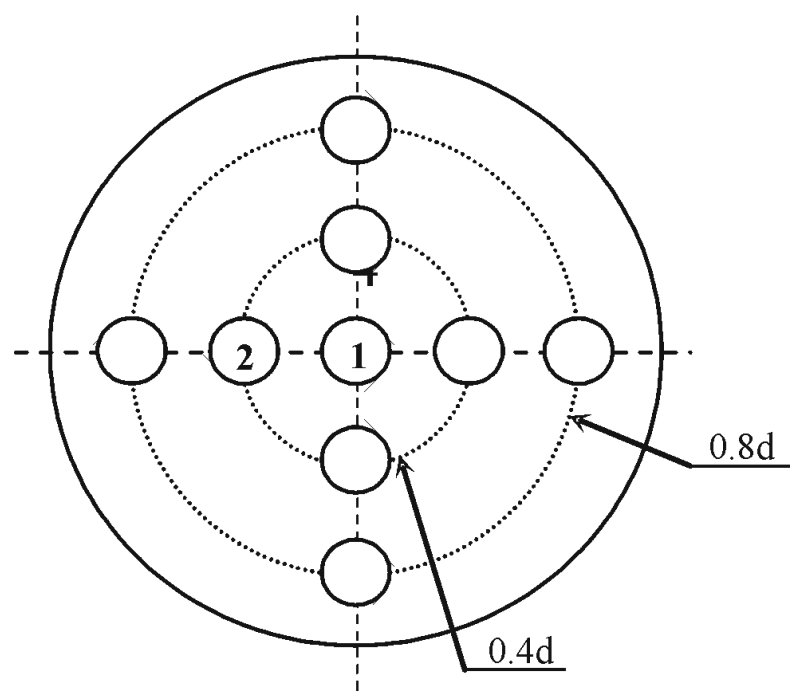

Fig. 2. Spark plugs location legend (d-cylinder diameter)

Rys. 2. Schemat rozmieszczenia świec zapłonowych (d-średnica cylindra)

Symulacje procesu spalania przeprowadzono dla paliwa ciekłego (benzyna) przy trzech wartościach współczynnika nadmiaru powietrza $\lambda=1,2,1,6$ i 2,0 oraz dla dwóch kombinacji świec zapłonowych: 1 i 1-2. Rozmieszczenie świec zapłonowych w komorze spalania przedstawia rys. 2 .

Modelowanie 3D procesu spalania rozpoczęto od kąta $220^{\circ} \mathrm{OWK}$, a zakończono na $494^{\circ} \mathrm{OWK}$, co odpowiada fazom rozrządu silnika badawczego, czyli zamknięciu zaworów dolotowych i początkowi otwarcia zaworów wylotowych. Dane wejściowe do programu pochodzą z badań eksperymentalnych [2], m.in. kąt wyprzedzenia zapłonu ustalono na $354^{\circ} \mathrm{OWK}$ dla $\lambda=1,2,350^{\circ} \mathrm{OWK}$ dla $\lambda=1,6$ oraz $344^{\circ} \mathrm{OWK}$ dla $\lambda=2,0$. Dane wyjściowe przedstawiono w postaci graficznej, jako slajdy z postprocesora GMV [1] oraz przebiegi ciśnienia (wartości średnie z całej objętości cylindra) w funkcji kąta obrotu wału korbowego.

Na rysunkach 3-5 przedstawiono rozkład temperatury w komorze spalania, jaki wystąpił przy poszczególnych wartościach współczynnika nadmiaru powietrza i dla kolejnych konfiguracji świec oraz przebiegi ciśnienia w funkcji kąta obrotu wału korbowego. Czasoprzestrzenny rozkład temperatury pokazano dla położenia tłoka w zewnętrznym zwrotnym położeniu (ZZP).

Rozkład temperatury oraz przebieg ciśnienia w funkcji kąta obrotu wału korbowego dla współczynnika nadmiaru powietrza $\lambda=1,2$ przedstawiono na rys. $3-5$.

Z rysunków 3 i 4 wynika, że zastosowanie dwóch świec zapłonowych przyspieszyło proces spalania, ponieważ 


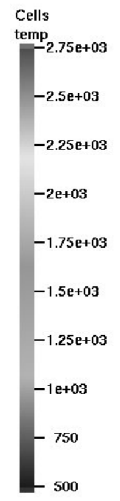

Fig. 3. Temperature distribution for central spark plug at $\lambda=1.2$ and TDC Rys. 3. Rozklad temperatury dla świecy centralnej $w$ ZZP dla $\lambda=1,2$

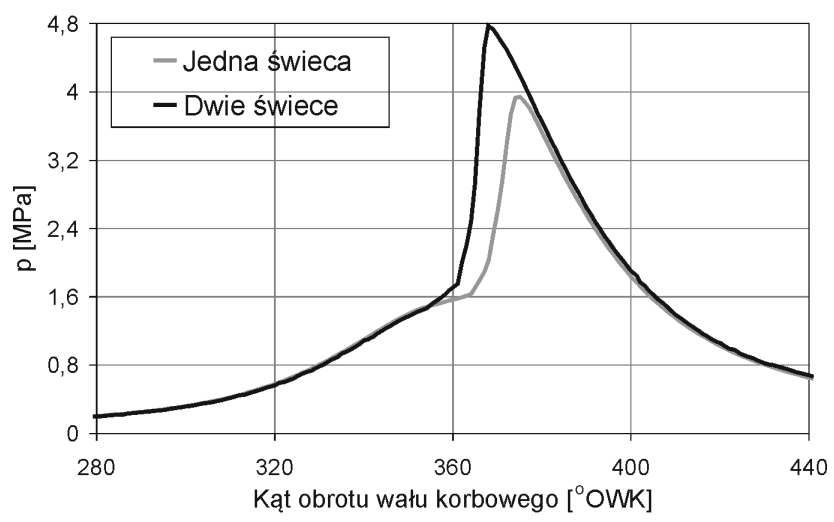

Fig. 5. In-cylinder pressure courses for two spark plugs configurations at $\lambda=1.2$

Rys. 5. Przebieg ciśnienia $w$ cylindrze modelu silnika dla jednej $i$ dwóch świec zapłonowych przy $\lambda=1,2$

In the spark plugs configuration, the modelled pressure is higher (Fig. 5) and its maximum (4.8 MPa) occurs earlier $(368 \mathrm{CA})$ than in one spark plug configuration $\left(\mathrm{p}_{\max }=3.9\right.$ $\mathrm{MPa}$ at $375 \mathrm{CA}$ ).

The following figures present combustion process modelling results at increased air excess number to 1.6.

ther mixture impoverishment caused reduction of maximum temperature value (lower than $2400 \mathrm{~K}$ ).

The area of charge of high temperature for two spark plugs (Fig. 7) was significantly smaller than for $\lambda=1.2$ (Fig. $4)$, although the ignition was about $4 \mathrm{CA}$ earlier.
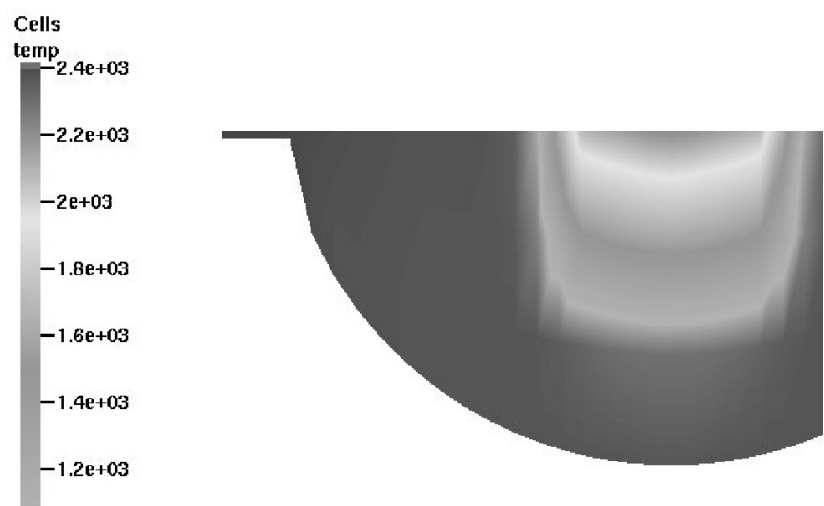

Fig. 6. Temperature distribution for central spark plug at $\lambda=1.6$ and TDC Rys. 6. Rozkład temperatury dla świecy centralnej $w$ ZZP dla $\lambda=1,6$
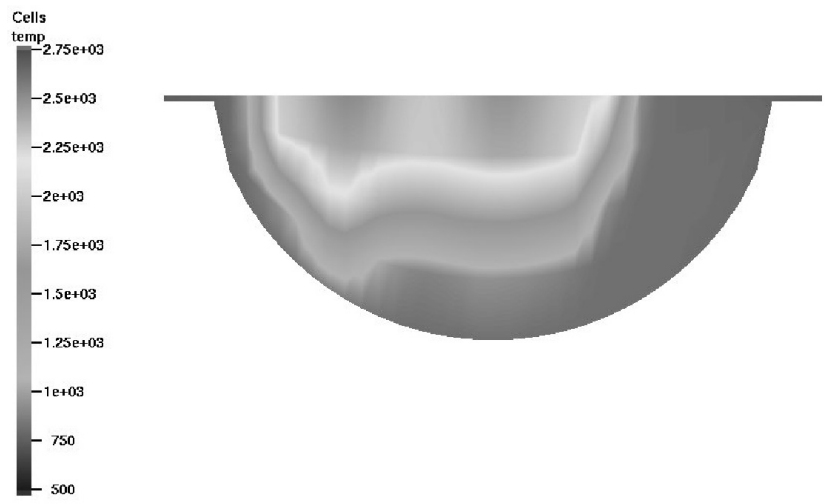

Fig. 4. Temperature distribution for two spark plugs at $\lambda=1.2$ and TDC Rys. 4. Rozkład temperatury dla dwóch świec $w$ ZZP dla $\lambda=1,2$

większa część ładunku uległa spalaniu i osiągnęła wysokie temperatury rzędu $2000 \mathrm{~K}$. Wzrosła również maksymalna temperatura występująca w cylindrze i przy położeniu tłoka w ZZP wyniosła ok. $2700 \mathrm{~K}$ przy dwóch świecach zapłonowych oraz ok. $2500 \mathrm{~K}$ dla pracującej jednej świecy zapłonowej.

Ciśnienie maksymalne w cylindrze (rys. 5) również było wyższe dla układu dwóch świec zapłonowych i jego maksimum (4,8 MPa) pojawiło się znacznie wcześniej $\left(368^{\circ} \mathrm{OWK}\right)$ niż przy jednej świecy zapłonowej $\left(\mathrm{p}_{\max }=3,9\right.$ MPa przy $375^{\circ} \mathrm{OWK}$ ).

Rysunki 6-8 przedstawiają wyniki modelowania procesu spalania dla zwiększonej wartości współczynnika nadmiaru powietrza do $\lambda=1,6$.

Dalsze zubożenie mieszanki spowodowało zmniejszenie maksymalnych wartości temperatury (poniżej $2400 \mathrm{~K}$ ), w porównaniu do poprzednich nastaw współczynnika nadmiaru powietrza. Obszar ładunku o wysokiej temperaturze, dla dwóch świec zapłonowych (rys. 7), był już znacznie mniejszy niż dla $\lambda=1,2$ (rys. 4 ), choć zapłon był tutaj wcześniejszy o $4^{\circ} \mathrm{OWK}$.

Stwierdzono również spadek maksymalnych wartości ciśnienia, zarówno w przypadku modelu silnika pracującego na jednej, jak i na dwóch świecach zapłonowych - rys. 8 . Dla zapłonu pojawiającego się w osi cylindra ciśnienie to spadło do wartości $3,8 \mathrm{MPa}$ przy $378^{\circ} \mathrm{OWK}$, natomiast dla dwóch świec do wartości 4,3 MPa przy $372^{\circ} \mathrm{OWK}$.
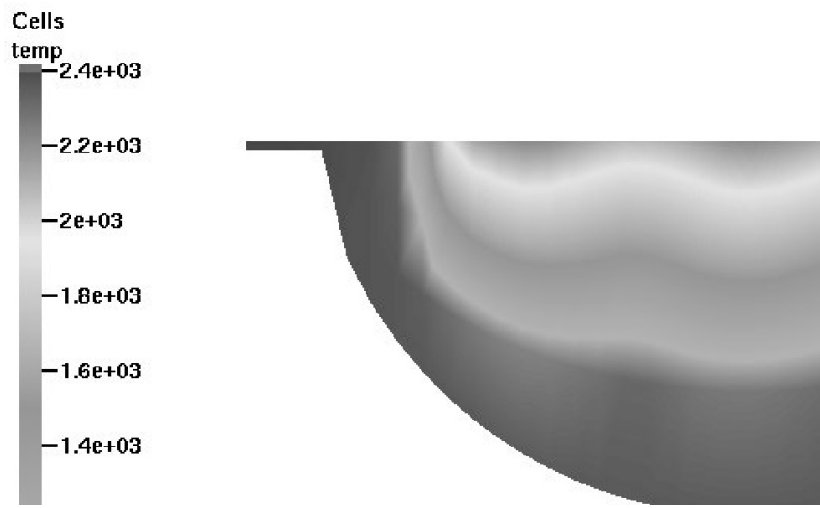

Fig. 7. Temperature distribution for two spark plugs at $\lambda=1,6$ and TDC Rys. 7. Rozkład temperatury dla dwóch świec $w$ ZZP dla $\lambda=1,6$ 
In comparison to previous air excess number value, furReduction of maximum pressure value for the engine model working on one and on two spark plugs was stated (Fig. 8). In case of the ignition in the cylinder axis the pressure dropped to the value of $3.8 \mathrm{MPa}$ at $378 \mathrm{CA}$, whereas it dropped to the value of $4.3 \mathrm{MPa}$ at $372 \mathrm{CA}$ for two spark plugs.

The temperature distribution as well as pressure courses (mean values for the whole cylinder volume) in function of crank angle at air excess number equal 2.0 are shown in Fig. 9 to 11 .

Further increase in air excess number to $\lambda=2.0$, caused reduction of maximal temperature value in the engine cylinder (Fig. 9 and 10). The maximal combustion temperature in TDC was appropriately $2100 \mathrm{~K}$ in case of two spark plugs and $2000 \mathrm{~K}$ in case of one active spark plug.

So high mixture impoverishment also caused reduction of maximal pressure in the engine cylinder value (Fig. 11). For the configuration with one spark plug the modelled pressure reached maximal value equal only $2.1 \mathrm{MPa}$ at 388 CA. In comparison with richer mixtures it is more than $45 \%$ decrease. However, pressure value for two spark plugs configuration was equal $3.0 \mathrm{MPa}$ at $379 \mathrm{CA}$. It is $38 \%$ less in comparison with $\lambda=1.2$ and $30 \%$ compared to $\lambda=1.6$.

For one spark plug configuration the combustion process was improper and very protracted as shown in Fig. 11
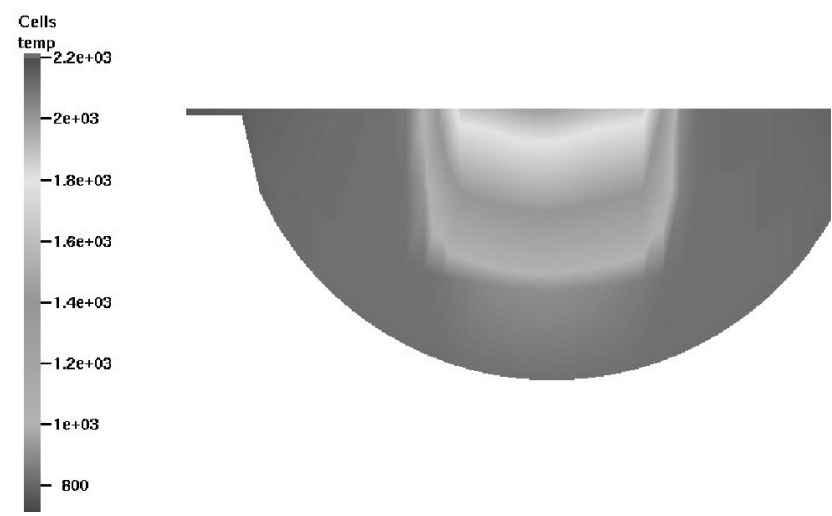

Fig. 9. Temperature distribution for central spark plug at $\lambda=2.0$ and TDC Rys. 9. Rozktad temperatury dla świecy centralnej $w$ ZZP dla $\lambda=2,0$

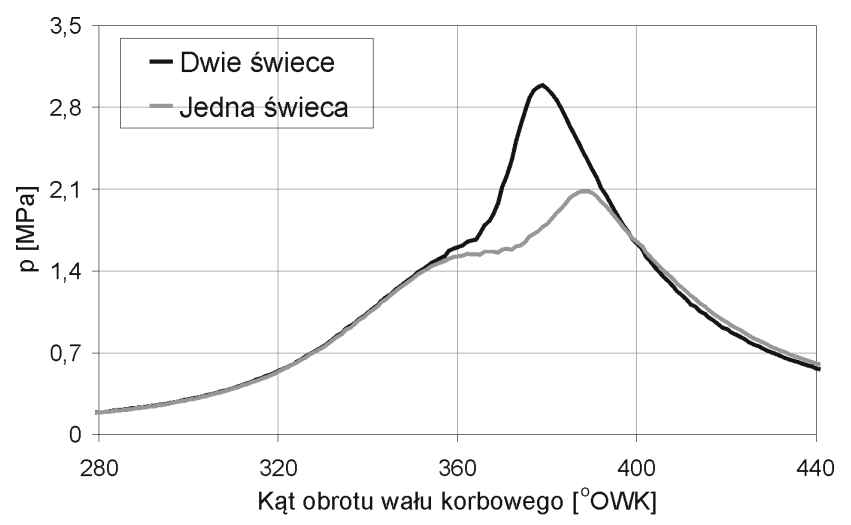

Fig. 11. In-cylinder pressure course for one and two spark plugs configurations at $\lambda=2.0$

Rys. 11. Przebieg ciśnienia w cylindrze modelu silnika dla jednej i dwóch świec zaptonowych przy $\lambda=2,0$

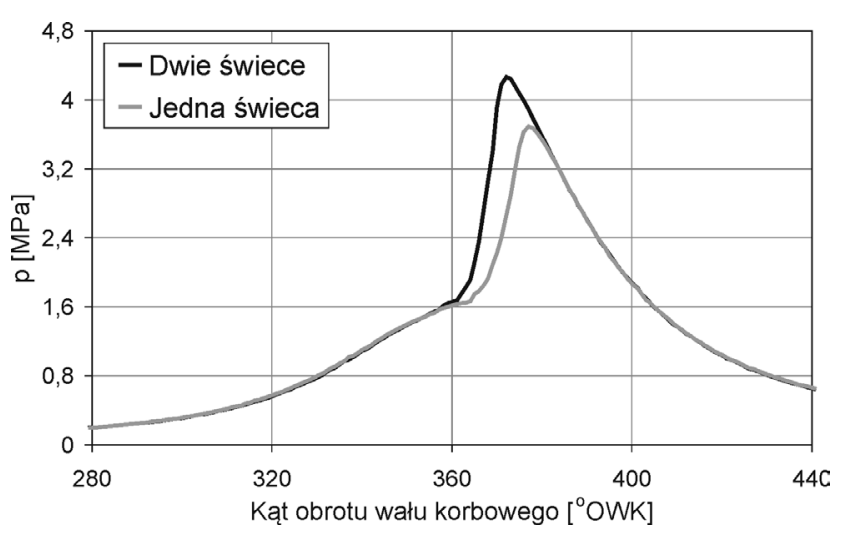

Fig. 8. In-cylinder pressure courses for two spark plugs configurations at $\lambda=1.6$

Rys. 8. Przebieg ciśnienia $w$ cylindrze modelu silnika dla jednej $i$ dwóch świec zapłonowych przy $\lambda=1,6$

Czasoprzestrzenny rozkład temperatury oraz przebiegi ciśnienia (wartości średnie dla całej objętości komory spalania) w funkcji kąta obrotu wału korbowego dla współczynnika nadmiaru powietrza $\lambda=2,0$ przedstawiono na rys. 9-11.

Dalsze zwiększanie wartości współczynnika nadmiaru powietrza do $\lambda=2,0$ spowodowało dalszy spadek maksymalnych wartości temperatury w cylindrze modelu silnika - rys. 9 i 10. Maksymalna temperatura spalania, przy położeniu tłoka w ZZP, wyniosła odpowiednio ok. $2100 \mathrm{~K}$ przy
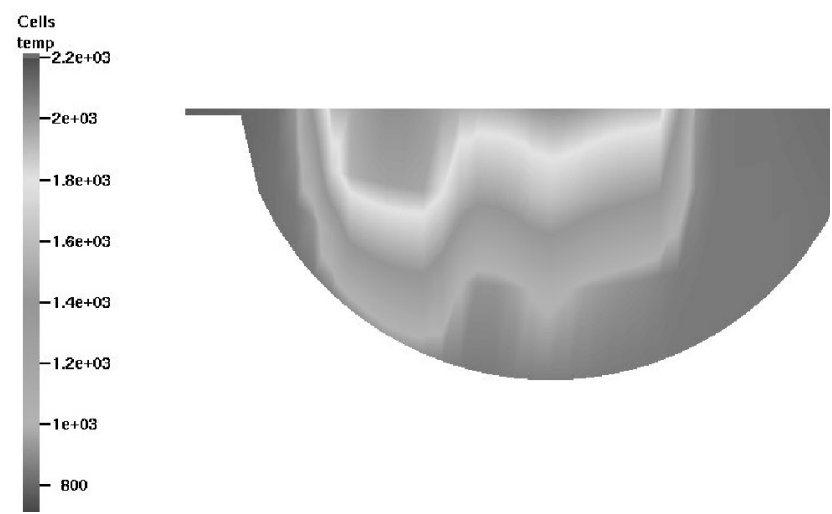

Fig. 10. Temperature distribution for two spark plugs at $\lambda=2.0$ and TDC Rys. 10. Rozkład temperatury dla dwóch świec $w$ ZZP dla $\lambda=2,0$

dwóch świecach zapłonowych oraz ok. $2000 \mathrm{~K}$ dla pracującej jednej świecy zapłonowej.

Tak duże zubożenie mieszanki spowodowało również znaczny spadek maksymalnych wartości ciśnienia w cylindrze modelu silnika - rys. 11. Dla konfiguracji z jedna świecą zapłonową modelowane ciśnienie osiągnęło wartość maksymalną równą zaledwie $2,1 \mathrm{MPa}$ przy $388^{\circ} \mathrm{OWK}$, co daje ponad 45-procentowy spadek wartości tego parametru w porównaniu z mieszankami bogatszymi. Natomiast odpowiednia wartość ciśnienia dla układu z dwoma świecami wyniosła 3,0 MPa przy $379^{\circ} \mathrm{OWK}$ i jest to spadek o $38 \%$ w porównaniu do $\lambda=1,2$ oraz o $30 \%$ w porównaniu do $\lambda=1,6$.

Z przebiegu ciśnienia w cylindrze (rys. 11) widać, że dla jednej świecy zapłonowej spalanie było niepoprawne, 
depicting the in-cylinder pressure course. The improvement of combustion process by its acceleration and maximum pressure value increase was caused by applying two spark plugs.

The influence of spark plugs configuration on the mass fraction burnt ratio in the function of crank angle was also verified in the paper. Rassweiler and Withrow method (R-W) [4] since 1938 has been used to define mass fraction burnt ratio $x(R-W)$. This method is a well known procedure of mass fraction burnt ratio setting, moreover it is commonly used as a reference method.

Two-point ignition significantly accelerated the combustion process in the modelled engine. It is depicted (Fig. 12 to 14$)$ by mass fraction burnt ratio $x(R-W)$ in the function of crank angle, calculated using application [7].

The above diagrams show the acceleration of combustion process for two spark plugs as the $50 \%$ mass fraction burnt

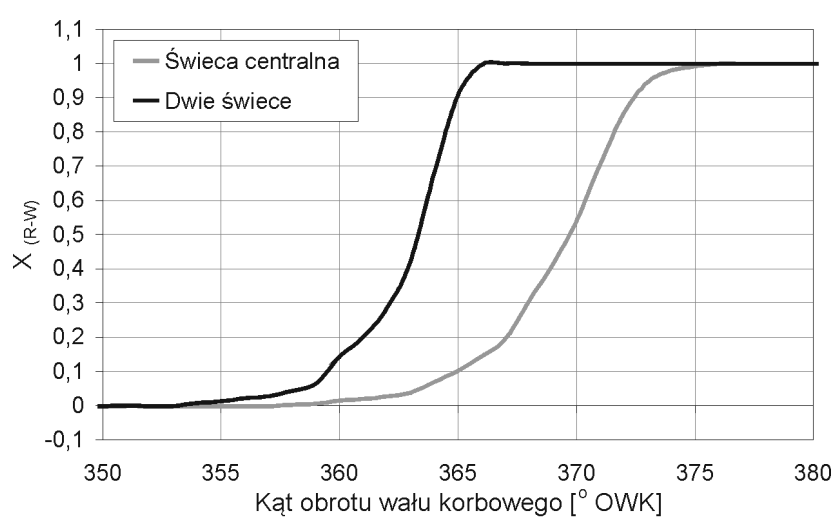

Fig. 12. Mass fraction burnt ratio for one and two spark plugs at $\lambda=1.2$ Rys.12. Udział masowy spalonego paliwa dla jednej i dwóch świec zapłonowych przy $\lambda=1,2$

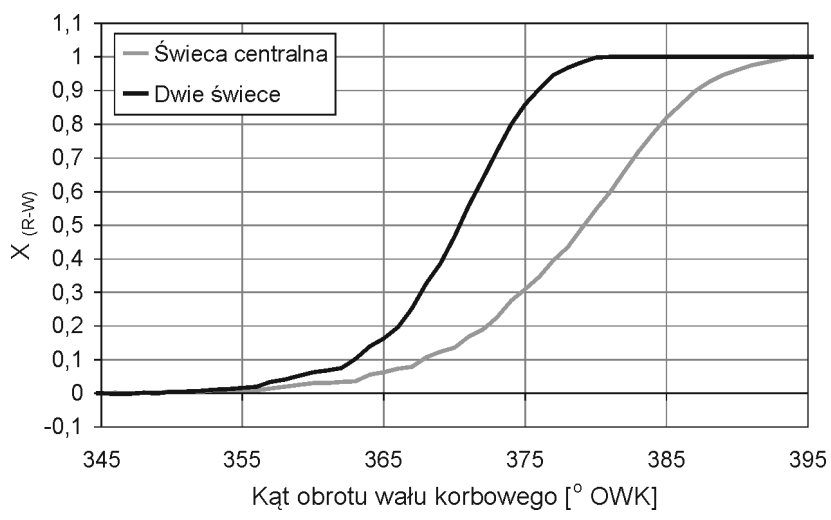

Fig. 14. Mass fraction burnt ratio for one and two spark plugs at $\lambda=2.0$

Rys. 14. Udział masowy spalonego paliwa dla jednej i dwóch świec zaptonowych przy $\lambda=2,0$

ratio value occurs earlier than for one, central spark plug. The difference between the position of $50 \%$ mass fraction burnt ratio value for one and two spark plugs was $5 \mathrm{CA}$ for $\lambda=1.2$. The difference increased up to 9 CA (Fig. 15) for the leanest mixture $(\lambda=2.0)$.

The Fig. 15 shows that while the air excess number increases the combustion process extends. $50 \%$ mass fraction burnt ratio value was 369 CA for one spark plug and 364 bardzo przewlekłe. Dopiero zastosowanie dwóch świec zapłonowych spowodowało poprawę procesu spalania, jego przyspieszenie i wzrost maksymalnej wartości ciśnienia.

W dalszej części artykułu przedstawiono, w jaki sposób poszczególne konfiguracje świec zapłonowych wpływają na przebieg udziału masowego spalonego paliwa w funkcji kąta obrotu wału korbowego. Do określenia udziału spalonego paliwa $\mathrm{x}(\mathrm{R}-\mathrm{W})$ wykorzystano, opracowaną w $1938 \mathrm{r}$, metodę Rassweilera i Withrowa (R-W) [4], która jest najbardziej znaną i powszechnie uznawaną procedurą wyznaczania przebiegu zmian części spalonej, a często przy ocenie wyników przyjmowana jest za metodę referencyjną.

Dwupunktowy zapłon znacznie przyspieszył proces spalania w modelu silnika. Bardzo dobrze odzwierciedlają to przebiegi udziału masowego spalonego paliwa $\mathrm{x}(\mathrm{R}-\mathrm{W})$ w funkcji kąta obrotu wału korbowego, wyznaczone przy wykorzystaniu aplikacji [7], a przedstawione na rys. 12-14.

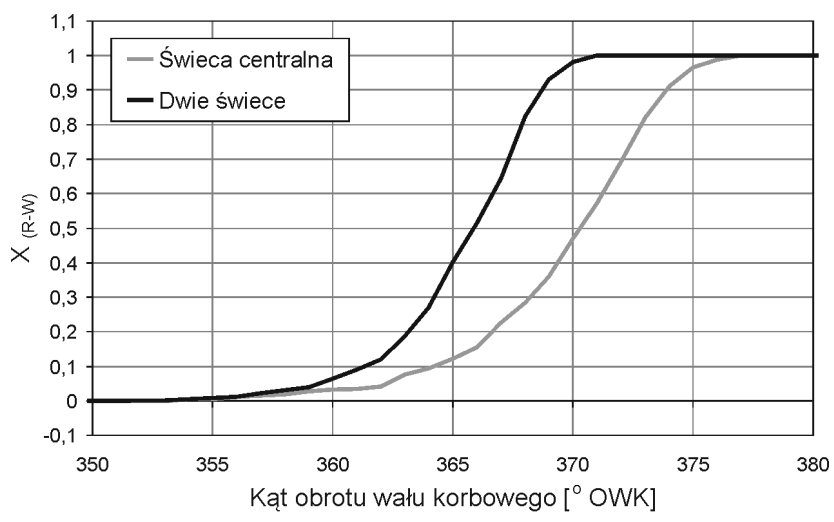

Fig. 13. Mass fraction burnt ratio for one and two spark plugs at $\lambda=1.6$ Rys.13. Udział masowy spalonego paliwa dla jednej $i$ dwóch świec zapłonowych przy $\lambda=1,6$

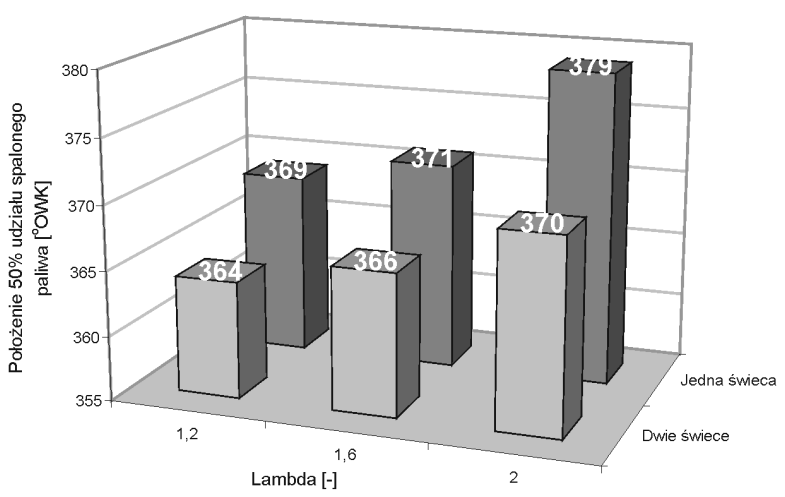

Fig. 15. Position of 50\% mass fraction burnt ratio value for one and two spark plugs in function of air excess number

Rys. 15. Położenie 50\% udziału spalonego paliwa dla jednej i dwóch świec zapłonowych $w$ funkcji współczynnika nadmiaru powietrza

Powyższe wykresy pokazują wyraźne przyspieszenie procesu spalania dla dwóch świec zapłonowych, ponieważ 50\% udziału spalonego paliwa pojawia się znacznie wcześniej niż dla jednej, centralnej świecy zapłonowej. Dla $\lambda=1,2$ różnica pomiędzy kątem położenia 50\% udziału spalonego paliwa, dla jednej i dwóch świec, wyniosła $5^{\circ} \mathrm{OWK}$, natomiast dla najuboższej mieszanki $(\lambda=2,0)$ różnica ta wzrosła do $9^{\circ} \mathrm{OWK}$ - rys. 15. 
CA for two spark plugs for $\lambda=1.2$. For the leanest mixture $(\lambda=2.0)$ the values were $379 \mathrm{CA}$ (one spark plug) and 370 CA (two spark plugs).

\section{Summary}

3D numerical modelling of combustion in two spark plugs engine proved that spark plug number increase improves combustion process of lean mixtures. The proper operation of engine model for one spark plug at air excess number $\lambda=2.0$ was almost impossible. The combustion was protracted, elongated in time, the maximal pressure in the cylinder was more than $45 \%$ lower in comparison with richer mixtures, $50 \%$ mass fraction burnt ratio value occurred at $379 \mathrm{CA}$ and it was $10 \mathrm{CA}$ later than in case of $\lambda=1.2$.

Activation of two spark plugs caused acceleration of combustion process and maximum pressure and temperature increase. It was the best noticeable at air excess number equal $\lambda=2.0$, where the increase of active spark plugs number up to two caused over $40 \%$ growth of maximal pressure value in the cylinder. Moreover, in the $50 \%$ mass fraction burnt ratio value, occurred $9 \mathrm{CA}$ earlier in comparison with one spark plug configuration. The results indicate that combustion of lean mixtures in the engine model can be feasible only by increasing the number of spark plugs. Two spark plugs application also caused significant growth of maximum pressure value for richer mixtures, it was $23 \%$ for $\lambda=1.2$ and $13 \%$ for $\lambda=1.6$. Whereas the position of $50 \%$ mass fraction burnt ratio value occurred $5 \mathrm{CA}$ earlier for both values of air excess number. To sum up it can be stated that the results of numerical modelling confirmed advantageous of application more spark plugs during lean mixtures combustion. The main disadvantage of these mixtures, which is very slow combustion was level down.

Artykut recenzowany

\section{Bibliography/Literatura}

[1] Amsden A.A.: KIVA-3V, a block-structured KIVA program for engines with vertical or canted valve, Los Alamos National Laboratory LA-UR-97-689, February 1997.

[2] Cupiał K., Kociszewski A.: Measurements and 3D modeling of combustion in multipoint spark ignition engine, Journal of KONES. Internal Combustion Engines, Vol. 9, No. 3-4, s. 80-87, 2002.

[3] Cupiał K., Sosnowski M., Jamrozik A., Kociszewski A., Tutak W.: Flame Kernel Formation Around a Spark Plug of SI Engine Using KIVA-3V with Standard and Newly Developed Ignition Model, Silniki Spalinowe R.46 nr SC2 , s. 203-206, 2007.

[4] Heywood J.B.: Internal combustion engine fundamentals, McGraw - Hill Book Company 1988.

[5] Jamrozik A., Tutak W., Kociszewski A., Sosnowski M.: Numerical Analysis of Influence of Prechamber Geometry in IC Engine with Two Stage Combustion System on Engine Work Cycle Parameters, Journal of KONES Powertrain and Transport, Vol 13, No 2, European Science Society of Powertrain and Transport Publication, Warsaw 2006.

[6] Löhner K., Müller H.: Gemischbildung und Verbrennung im Ottomotor, [in:] List H., Die Verbrennungskraftmaschine, Springer-Verlag, Wien-New York 1967.

[7] Smereka M.: Program do analizy udziału masowego spalonego paliwa, Instytut Maszyn Tłokowych i Techniki Sterowania, Częstochowa 2003.
Z rysunku 15 wynika, że wraz ze wzrostem współczynnika nadmiaru powietrza wydłuża się proces spalania. Dla $\lambda=1,2$ kąt położenia $50 \%$ udziału spalonego paliwa wynosił $369^{\circ} \mathrm{OWK}$ dla jednej świecy oraz $364^{\circ} \mathrm{OWK}$ dla dwóch świec, natomiast dla najuboższej mieszanki $(\lambda=2,0)$ wartości te wyniosły odpowiednio $379^{\circ} \mathrm{OWK}$ (jedna świeca) oraz $370^{\circ} \mathrm{OWK}$ (dwie świece).

\section{Podsumowanie}

Trójwymiarowe modelowanie procesu spalania w silniku dwuświecowym potwierdziło postawioną we wstępie tezę, że zwiększenie liczby świec zapłonowych poprawia proces spalania mieszanek bardzo ubogich. Praca modelu silnika przy włączonej jednej świecy zapłonowej dla współczynnika nadmiaru powietrza $\lambda=2,0$ była prawie niemożliwa. Spalanie odbywało się w sposób przewlekły, było bardzo rozciągnięte w czasie, ciśnienie maksymalne w cylindrze było o ponad $45 \%$ niższe w porównaniu $\mathrm{z}$ mieszankami bogatszymi, a kąt położenia 50\% udziału spalonego paliwa wyniósł aż $379^{\circ} \mathrm{OWK}$ i było to o $10^{\circ} \mathrm{OWK}$ później niż w przypadku $\lambda$ $=1,2$. Włączenie dwóch świec zapłonowych spowodowało przyspieszenie procesu spalania i wzrost maksymalnych wartości ciśnienia i temperatury. Najbardziej widoczne było to dla współczynnika nadmiaru powierza $\lambda=2,0$, gdzie zwiększenie liczby świec do dwóch spowodowało ponad 40-procentowy przyrost wartości maksymalnej ciśnienia w cylindrze. Natomiast 50\% udziału spalonego paliwa, dla tego przypadku, pojawiło się wcześniej o $9^{\circ} \mathrm{OWK}$ w porównaniu do układu $\mathrm{z}$ jedną świecą. Wyniki wskazują, że spalanie w modelu silnika mieszanek o tak dużym zubożeniu może odbywać się jedynie przy zwiększonej liczbie świec zapłonowych. Biorąc pod uwagę mieszanki bogatsze $(\lambda=1,2$ i 1,6$)$, zastosowanie dwóch świec zapłonowych również spowodowało znaczny przyrost wartości ciśnienia maksymalnego, mianowicie dla $\lambda=1,2$ było to $23 \%$, a dla $\lambda=1,6-13 \%$. Natomiast położenie $50 \%$ udziału spalonego paliwa wystąpiło wcześniej o $5^{\circ} \mathrm{OWK}$ dla obu wartości współczynnika nadmiaru powietrza.

Można zatem stwierdzić, że wyniki modelowania potwierdziły korzystny wpływ zastosowania większej liczby świec zapłonowych przy spalaniu mieszanek zubożonych. Została zniwelowana główna wada tych mieszanek, jaką jest powolne, a wręcz przewlekłe spalanie.

[8] Tutak W., Jamrozik A., Kociszewski A., Sosnowski M.: The influence of initial swirl profile on modelled piston engine work cycle parameters, XIV Ukrainian-Polish Conference on "CAD in Machinery Design. Implementation and Educational Problems.” CADMD`2006, Polyana, Ukraine, 22-23 May 2006.

[9] Yamamoto H., Horita S., Matsuoka T.: Surrounding combustion process (SCP) - new concept for lean burn engine, SAE Paper 920058, 1992.

Mr Arkadiusz Kociszewski, PhD, MEng - doctor in the Faculty of Mechanical Engineering and Computer Science of Częstochowa University of Technology.

Dr inż. Arkadiusz Kociszewski - adiunkt na Wydziale Inżynierii Mechanicznej i Informatyki Politechniki Częstochowskiej.

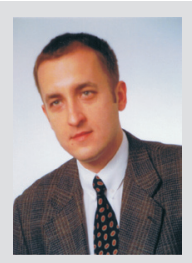

